\title{
Comparision of Chest Tube and Intrapleural Catheter Applied for Benign Pleural Effusions
}

\author{
Benign Plevral Efüzyonlarda Uygulanan Göğüs Tüpü ve Intraplevral Kataterlerin \\ Karşılaștırılması
}

\section{(1) Murat Sarıçam}

Tekirdağ Namık Kemal University Faculty of Medicine, Department of Thoracic Surgery, Tekirdağ, Turkey

\section{Abstract}

Objectives: The aim of our current study was to compare the chest tube and intrapleural catheter applied for non-malignant pleural effusions. Materials and Methods: Between March 2016 and April 2017, 33 patients with pleural effusion but bearing no history of malignancy were accepted to the study. After pathological examination of the effusions, the cases diagnosed as malignant pleural effusion were excluded. Twenty eight French chest tubes and 8 French intrapleural catheters (B. Braun, Melsungen, Germany) were applied for drainage. The patients were evaluated in terms of age, gender, the etiology of the effusion, the side of the procedure, the amount of drainage, length of in-hospital stay, the level of pain and complications. The pain level was calculated using Visual Analogue scale (VAS). The data was evaluated statistically by Mann-Whitney U test. A $p$ value $<0.05$ was accepted as being statistically significant.

Results: Among 20 male (61\%) and 13 female (39\%) patients, we applied chest tube in $14(42 \%)$ and intrapleural catheter in 19 (58\%) cases. Mean age of our patients was calculated as 66.8 (range: 28-93) years. The procedures were performed at right side in 20 (61\%) and at left side in 13 (39\%) cases. The mean drainage amount was calculated as 2219 (range: 500-4700) mL. Fourteen cases (42\%) had parapneumonic effusions while the cause of the effusions were heart failure in $15(45 \%)$ and renal failure in $4(13 \%)$ cases. The mean duration of in-hospital stay was 4.93 days after chest tube application and 3.05 days for the patients treated with intrapleural catheter. The mean pain level calculated by VAS was 6.21 in chest tube group and 3.94 in intrapleural catheter group, respectively. One patient treated with chest tube suffered intercostal artery injury. When two groups were statistically analysed, significant difference was calculated for time of in-hospital stay $(p=0.0013)$ and level of pain ( $<<0.00001)$ in favour of pleural catheters.

Conclusion: The application of intrapleural catheter is may be preferred as a safe and comfortable treatment method in benign pleural effusions because it causes less pain and shortens in-hospital stay.

Key Words: Benign Pleural Effusion, Tube Thoracostomy, Chest Tube, Intrapleural Catheter

\section{Öz}

Amaç: Çalışmamızın amacı malign olmayan plevral efüzyonlarda uygulanan göğüs tüpü ve intraplevral kataterlerin karşılaştırılmasıdır.

Gereç ve Yöntem: Mart 2016 ve Nisan 2017 tarihleri arasında yapılan çalışmaya plevral efüzyon tanısı olan ancak öncesinde malignite hikayesi bulunmayan 33 hasta kabul edildi. Plevral efüzyonlarının patolojik incelemesi malign plevral efüzyon olarak raporlanan hastalar çalışmadan çıkartıldı. Drenaj amacıyla 28 French göğüs tüpleri ve 8 French intraplevral kataterler (B. Braun, Melsungen, Almanya) kullanıldı. Çalışmaya katılan hastalar yaş, cinsiyet, efüzyonun etiyolojisi, işlem uygulanan taraf, drenaj miktarı, hastanede kalış süresi, ağrı düzeyi ve komplikasyonlar açısından değerlendirildi. Ağrı düzeyi Visual Analog skala (VAS) ile hesaplandı. Elde edilen veriler istatistiksel olarak Mann-Whitney U testi ile değerlendirildi. 0,05 sayısından küçük olan p değeri istatistiksel olarak anlamlı kabul edildi.

Bulgular: Toplam 20 erkek (\%61) ve 13 kadın (\%39) hastadan 14 tanesine (\%42) göğüs tüpü, 19 tanesine (\%58) intraplevral katater takıldı. Hastaların yaş ortalaması 66,8 (28-93) yıl olarak hesaplandı. İşlemler 20 hastada (\%61) sağ, 13 hastada (\%39) ise sol taraftan uygulandı. Ortalama drenaj miktarı 2219 (500-4700) mL olarak ölçüldü. On dört olguda (\%42) parapnömonik efüzyon saptanırken, plevral efüzyonun nedeni 15 hastada $(\% 45)$ kalp yetmezliği ve 4 hastada (\%13) ise böbrek yetmezliği idi. Hastanede ortalama kalış süresi göğüs tüpü takılan hastalarda 4,93 gün iken

Address for Correspondence/Yazışma Adresi: Murat Sarıçam MD,

Tekirdağ Namık Kemal University Faculty of Medicine, Department of Thoracic Surgery, Tekirdağ, Turkey

Phone: +90 5336961299 E-mail: drsaricam@gmail.com ORCID ID: orcid.org/0000-0003-3469-5798

Received/Geliş Tarihi: 02.08.2017 Accepted/Kabul Tarihi: 07.03.2018

๑Copyright 2018 Ankara University Faculty of Medicine

Journal of Ankara University Faculty of Medicine is published by Galenos Publishing House.

All content are under CC BY-NC-ND license. 
intraplevral katater ile tedavi edilen hastalarda bu değer 3,94 gün olarak hesaplandı. Sadece göğüs tüpü takılan bir hastada interkostal arter yaralanması gelişti. İki grup istatistiksel olarak analiz edildiğinde hastanede kalış süresi $(p=0,0013)$ ve ağrı düzeyi $(p<0,00001)$ açısından anlamlı fark saptandı.

Sonuç: İntraplevral kataterler, benign plevral efüzyonlarda, daha az ağrıya sebep olması ve hastanede kalış süresini azaltması nedeniyle güvenli ve konforlu bir tedavi yöntemi olarak tercih edilebilir.

Anahtar Kelimeler: Benign Plevral Efüzyon, Tüp Torakostomi, Göğüs Tüpü, İntraplevral Katater

\section{Introduction}

Pleural fluid is produced by parietal pleura and interstitial tissue of the lungs. Pleural effusions occur as a result of an imbalance between the flow and absorption of the pleural fluid (1). The cause for the collection of the effusion depends on the primary disease. The increase in the production of pleural fluid, the decrease in the lymphatic absorption or both of the situations together cause pleural effusion gather in the pleural cavity. The increased systemic venous pressure in Superior vena cava syndrome, hypoalbuminemia in cirrhosis, the intraabdominal fluid passing through diaphragma or the increased levels of pleural fluid production in malignant intra-thoracic diseases may be examples for the collection of pleural effusions (2).

Pleural effusions may be assessed with clinical and radioligical methods. A small amount of fluid is completely asymptomatic. However, as the amount of effusion increases, the patients suffer reduced exercise tolerance or shortness of breath. Chest X-rays require $200-500 \mathrm{~mL}$ of fluid to be evident. The features of a chest $X$-ray include blunting of the costophrenic angle, a meniscus seen laterally and sloping medially and in large effusions; mediastinal shift occuring away from the effusion (Figure 1). Ultrasound detects small amounts of fluid that cannot be identified by X-rays while it is also effective in guiding thoracocentesis even in small collections. Computerized tomography (CT) is succesful in detecting small amounts of fluid, also in identifying underlying intra-thoracic causes and subdiaphragmatic diseases (Figure 2).

Although tube thoracostomy has been accepted as the standard method of treatment for pleural effusions, small-bore intrapleural catheters may be preferred for their low potential of complications and morbidity (3).

Herein, we aim to compare chest tubes and intrapleural catheters applied for benign pleural effusions.

\section{Materials and Methods}

Our study is a retrospective evaluation of patients who had chest tubes and intrapleural catheters between March 2016 and April 2017 in our instution.

The patients with pleural effusions who had chest drainage were included in the study. After checking out pathological

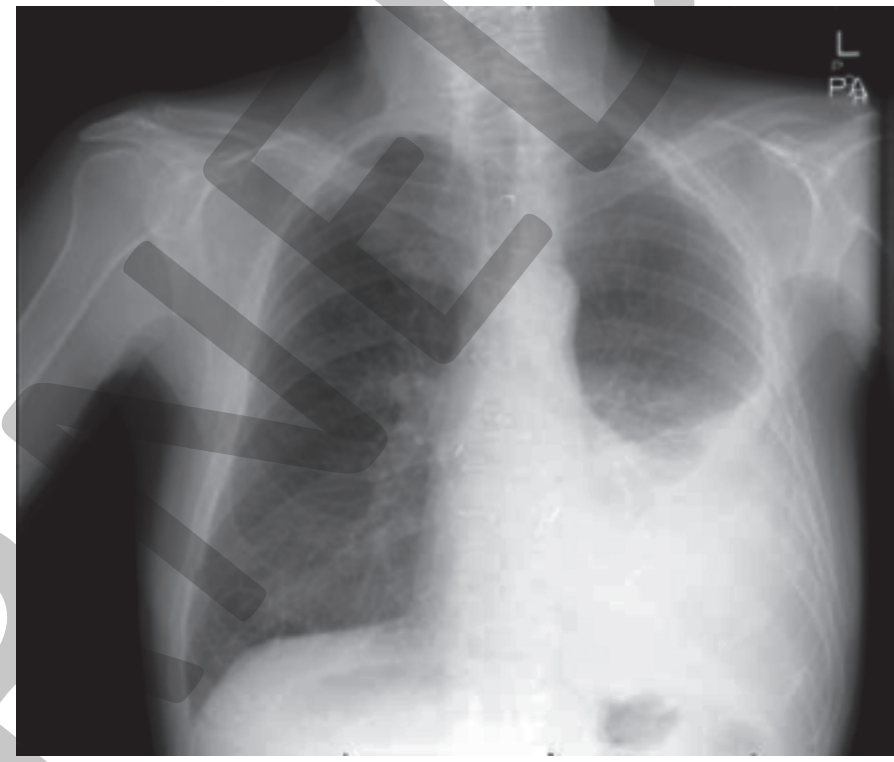

Figure 1: Chest X-ray of a left-sided pleural effusion

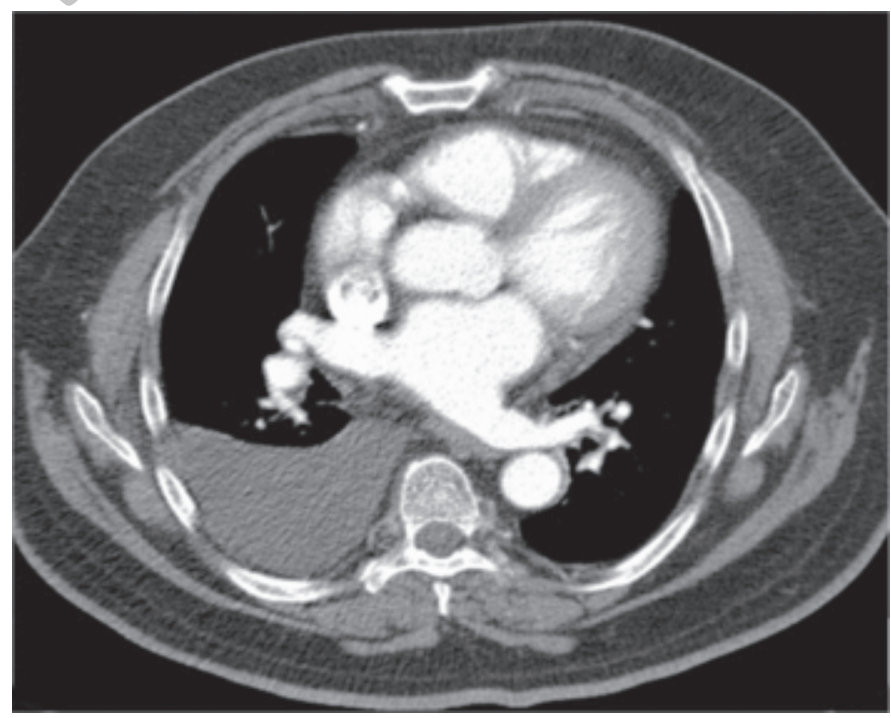

Figure 2: Comptured tomography demonstrating a pleural effusion in the right hemithorax

examination reports, cases reported as malignant effusions and the patients with radiologic and clinical evidence of loculated effusions or empyema were excluded.

Diagnosis of pleural effusions was based on clinical, chest $\mathrm{X}$-ray and $\mathrm{CT}$ scan findings. Medical examination and coagulation profile were done to all patients. The diagnosis was confirmed by thoracocentesis. All interventions were made bedside under 
local anesthesia with $10 \mathrm{~mL}$ lidocaine $2 \%$. The site of insertion was decided by thoracocentesis.

Twenty eight French chest tubes and 8 French intrapleural catheteres (B. Braun, Melsungen, Germany) were applied for drainage.

The samples of thoracocentesis material were delivered for distinction of exudate and transudate characteristic of the fluid, also microbial culture studies and pathological examination.

All the patients were evaluated by daily chest X-rays. The decision to remove chest tubes and catheters was made upon the clearance of the opasity on chest radiographs and the daily drainage amount less than $100 \mathrm{~mL}$.

The patients were examined in terms of age, gender, the etiology of the effusion, the side of the procedure, the amount of the drainage, time of in-hospital stay, the level of pain and complications. The pain level was calculated with Visual Analogue scale (VAS). The data was evaluated statistically by Mann-Whitney U test.

\section{Results}

Thirty three patients had chest tubes and intrapleural catheters for the treatment of benign pleural effusion over one-year period in our clinic. Chest tubes were inserted in 14 patients while 19 patients had intrapleural catheters. Twenty patients were male and 13 patients were female. The mean age was 66.8 years (range: 20-93 years). Fourteen patients had parapneumonic effusion while the effusion developed upon heart failure in 15 patients and renal failure in 5 cases, respectively. The procedures were applied at right side for 20 and at left side for 13 cases.

Mean amount of drainage was $2478 \mathrm{~mL}$ in chest tube and $2028 \mathrm{~mL}$ in the catheter group. Mean duration in-hospital stay was 4.93 days and 3.05 days for the patients who had chest tubes and catheters, respectively. Average of pain score was calculated as 3.94 in cases with catheters and 6.21 in patients with chest tubes. Data concerning demographic and clinical analysis of the patients is given in Table 1.

Only one patient suffered intercostal artery injury during chest tube insertion. Thoracotomy was performed and he was discharged on the fourth day following surgery.

\section{Discussion}

The interest for this study has raised because of the aim to compare chest tubes and seemingly less invasive and more comfortable intrapleural catheters applied for benign pleural effusions. The literature mainly consists of data which compares these two treatment methods for malignant pleural effusions.
Table 1: Demographic and clinical data of the patients who had pleural drainage

\begin{tabular}{llll}
\hline Parameters & $\begin{array}{l}\text { Tube } \\
\text { thoracostomy }\end{array}$ & $\begin{array}{l}\text { Intrapleural } \\
\text { catheter }\end{array}$ & Total \\
\hline Number of patients & 14 & 19 & 33 \\
\hline Age (mean, years) & 63.3 & 71.5 & 66.8 \\
\hline $\begin{array}{l}\text { Gender (n) } \\
\text { Male }\end{array}$ & 8 & 12 & 20 \\
Female & 6 & 7 & 13 \\
\hline $\begin{array}{l}\text { Side of procedure (n) } \\
\text { Right }\end{array}$ & 12 & 8 & 20 \\
Left & 2 & 11 & 13 \\
\hline $\begin{array}{l}\text { Amount of drainage } \\
\text { (mean, mL) }\end{array}$ & 2478 & 2028 & 2219 \\
\hline $\begin{array}{l}\text { In-hospital stay } \\
\text { (mean, days) }\end{array}$ & 4.93 & 3.05 & 3.84 \\
\hline $\begin{array}{l}\text { Pain score } \\
\text { (average calculated by VAS) }\end{array}$ & 6.21 & 3.94 & 1 \\
\hline \begin{tabular}{l} 
Complications \\
\hline
\end{tabular} & 1 & 0 & 4.91 \\
\hline
\end{tabular}

VAS: Visual Analogue scale

Mean amount of drainage for chest tubes and catheters were 2478 and $2028 \mathrm{~mL}$, respectively. When statistically examined, there is no significant difference between these two groups ( $p=0.05705$ ). Clementsen et al. (4) also reported that they found no significant difference in the amount of pleural fluid when they applied large-bore chest tubes or small percutaneous catheter in the manner of draining pleural effusions.

The average duration of in-hospital stay was 4.93 days in chest tube group and 3.05 days for the catheter group. This data reveals a statistically significant difference between two groups of patients ( $p=0.00013$ ). Among some recent studies discussing the duration of pleural fluid drainage via pleural catheters Bediwy and Amer (5) calculated 5.8 days and Parulekar et al. (6) reported six days of drainage time.

Mean score of pain calculated by VAS was 3.94 for catheter and 6.21 for chest tube groups. We realized significant difference compairing these two groups in terms of pain level $(p<0.00001)$. However, recent papers in the literature covers insufficient data with regards to calculating pain score in numeric expressions.

Among both of the study groups, only one patient with chest tube suffered a complication of intercostal artery injury. Kesieme et al. (7) report the complications of tube thoracostomy as tube malposition; reexpansion pulmonary edema; subcutaneous emphysema; cardiac ve vascular injuries. Reviewing the literature, it may be noticed that catheter insertion carries out a little risk for complications. Roberts et al. (8) reported 5\% and Liu et al. (9) announced 3\% of the patients developed serious complications as hemothorax, pneumothorax, solid organ perforation or vascular injuries due to procedure. 
Gammie et al. (10) demonstrated that the success rate was $86 \%$ without any complications when they applied intrapleural catheters for drainage.

\section{Conclusion}

As a result, insertion of intrapleural catheters for the treatment of benign pleural effusions does not bring out any disadvantage in draining the pleural fluid but shortens the length ofin-hospital stay, also developing less pain and fewer complications to patients. With both high success level and low complication rates, intrapleural catheters may be used safely and effectively for benign pleural effusions.

\section{Ethics}

Ethics Committee Approval: This was study Tekirdağ Namık Kemal University Ethics Committee approved (project no: 2017/123-001).

Informed Consent: It was taken.

Financial Disclosure: The author declared that this study received no financial support.

\section{References}

1. Gotsman I, Fridlender Z, Meirovitz A, et al. The Evaluation Of Pleural Effusions In Patients With Heart Failure. Am J Med 2001;111:375-378.

2. Kurkcuoglu C, Karaoglanoglu N, Eroglu A, et al. Videothoracoscopy For Pleural Effusion: A Review Of 47 Cases. Turkish J Thorac and Cardiovasc Surg 2000;8:712-714.

3. Munnell ER. Thoracic Drainage. Ann Thorac Surg 1997;63:1497-1502.

4. Clementsen $\mathrm{P}, \mathrm{Evald} \mathrm{T}$, Grode $\mathrm{G}$, et al. Treatment Of Malignant Pleural Effusion: Pleurodesis Using A Small Percutaneous Catheter. A Prospective Randomized Study. Respir Med 1998;92:593-596.

5. Bediwy AS, Amer HG. Pigtail Catheter Use For Draining Pleural Effusions Of Various Etiologies. Pulmonology 2012:1-6.

6. Parulekar W, Di Primio G, Matzinger F, et al. Use Of Small-bore vs Largebore Chest Tubes For Treatment Of Malignant Pleural Effusions. Chest 2001;120:19-25.

7. Kesieme E, Dongo A, Ezemba N, et al. Tube Thoracostomy: Complications And Its Management. Pulm Med 2012;2012:256878.

8. Roberts JS, Bratton SL, Brogan TV. Efficacy And Complications Of Percutaneous Pigtail Catheters For Thoracostomy In Pediatric Patients. Chest 1998;114:1116-1121.

9. Liu YH, Lin YC, Liang SJ, et al. Ultrasound-guided Pigtail Catheters For Drainage Of Various Pleural Diseases. Am J Emerg Med 2010;28:915-921.

10. Gammie JS, Banks MC, Fuhrman CR, et al. The Pigtail Catheter For Pleural Drainage: A Less Invasive Alternative To Tube Thoracostomy. JSL 1999;3:5761.

\section{ERRATUM}

DOI: $10.4274 /$ atfm. 65375

Journal of Ankara University Faculty of Medicine 2018;71(2):162-165

The article named "Sarıçam M. Comparision of Chest Tube and Intrapleural Catheter Applied for Benign Pleural Effusions. Journal of Ankara University Faculty of Medicine 2018;71(2):162-165" has been returned to its author due to ethical violation. 